\title{
Review
}

\section{Thin Cell Layer technology in ornamental plant micropropagation and biotechnology}

\author{
Jaime A. Teixeira da Silva \\ Faculty of Agriculture, Kagawa University, Miki-cho, Ikenobe, 2393, Kagawa-ken, 761-0795, Japan. Telfax: $+81(0) 72$ \\ 726 8178. E-mail: jaimetex@lycos.com. \\ Accepted 4 December 2003

\begin{abstract}
Thin cell layer (TCL) technology originated almost 30 years ago with the controlled development of have been successfully used in the micropropagation of many ornamental plant species whose previous in vitro regeneration was not successful using conventional methods. This review examines the fundamentals behind TCLs, and their application in ornamental plant micropropagation and transformation.
\end{abstract} \\ flowers, roots, shoots and somatic embryos on tobacco pedicel longitudinal TCLs. Since then TCLs
}

Key words: Chrysanthemum, lily, somatic embryogenesis, thin cell layer, tobacco, transformation.

\section{INTRODUCTION}

The mechanisms governing plant growth and development are one of the most fundamental and applied areas of modern plant research. Higher plants develop from a single-celled zygote into a multicellular organism through co-ordinated cell divisions, and when this process occurs without patterning, disorganized callus tissue is produced (Teixeira da Silva and Nhut, 2003). Body organization is generated by two distinct processes: the primary organization of the body, represented by the seedling, and including the shoot and root meristems, is laid down by embryonic pattern formation, while the meristems then take over to produce the adult plant during post-embryonic development. Plant organs are composed of ordered collections of various cell types differing in their shape, size, position, function and DNA content. Cell division, separation and morphogenesis are intimately connected, and ontogenesis is determined by the genome and is influenced by external signals. Correct control of the celldivision cycle is required for the elaboration and execution of developmental programmes, while patterning genes determine overall architecture of the plant. Cell division is a critical activity during the growth and development of a plant providing the building blocks for the differentiation of in vitro thin cell layers (TCLs) or in planta tissues and organs, and contributes to the overall size of the individual.

This review serves to introduce to readers the concept of a TCL, its model systems, and applications in higher plant tissue and organ culture, and genetic transformation. Moreover TCL technology is a solution to many of the issues currently hindering the efficient progress of ornamental and floricultural crop improvement, since it addresses the issue of plant breeding at the first stage of the problem: regeneration. Since the regeneration of specific organs may be effectively manipulated through the use of TCLs, in conjunction with specific controlled in vitro conditions and exogenously applied plant growth regulators (PGRs), many problems hindering the improvement of in vitro plant systems are potentially removed. I will demonstrate, through this comprehensive review, the truth of this claim, and that the application and success of this system in floricultural and ornamental crops is widespread. The possibilities of this tool for crop (ornamental and floricultural) improvement are endless, and go tightly hand-in-hand with molecular and genetic engineering tools. Moreover this system provides a means of mass propagation of a species of interest, and 
has thus profound potential economic spin-offs. The TCL system would provide a simple but efficient micropropagation system for countries in Africa with limited resources and facilities.

Although beyond the scope of this review, TCL technology has also been effectively used in the micropropagation of vegetable, leguminous, and medicinal plants, including Amaranthus edulis (amaranth), Beta vulgaris (sugar beet), Brassica napus (oilseed rape), Lupinus spp. (lupin), Panax ginseng (ginseng), and Phaseolus vulgaris (common bean) (Nhut et al., 2003b); cereals and grasses, including Digitaria sanguinalis (large crabgrass), Oryza sativa (rice), Sorghum bicolor (sorghum), and Zea mays (corn) (Nhut et al., 2003c); fruits, including Musa sp. (banana), Citrus spp. (orange, lemon, mandarin), Poncirus trifoliata (trifoliate orange), Cocos nucifera (coconut palm), Garcinia mangostana (mangosteen), Lycopersicon esculentum (tomato) (Nhut et al., 2003d); woody plants, including Bambusa spp. and Dendrocalamus spp. (bamboo), Manihot esculenta (cassava), Pinus radiata (Monterey pine), Paulownia fortunei (paulownia), Populus spp. (poplar), Pseudotsuga manziesii and Sequoiadendron spp. (conifers), Garcinia mangostana (garcinia/kokum), and Rosa spp. (rose) (Nhut et al., 2003e, 2003f).

\section{TCL CONCEPT AND SYSTEM}

The thin cell layer (TCL) system consists of explants of a small size excised from different plant organs (stems, leaves, floral inflorescences, flower primordia or floral organs, cotyledons, hypo-/epicotyl, apical zone or embryo), either longitudinally (ITCL), or transversally (tTCL). ITCLs contain only one tissue type, such as a monolayer of epidermal cells, whereas tTCLs include a small number of cells from different tissue-types: epidermal, cortical, cambium, perivascular and medullar tissue, parenchyma cells (Tran Thanh Van, 1980).

TCL systems allow for the isolation of specific cell or tissue layers, which, depending on the genetic state and epigenetic requirements, and in conjunction with strictly controlled growth conditions (light, temperature, $\mathrm{pH}$, PGRs, media additives and others) may lead to the in vitro induction of specific morphogenic programs. The capacity of a TCL to enter a program depends upon a number of factors, including correct signal perception and transduction, the capacity of the internal genetic machinery to respond and react to these signals and in the latter case, may depend on the physiological state and origin (tissue and organ) of the TCL, stress factors applied to the TCL, and apoptotic or gene silencing states of the tissue or cells within it. Should this first phase be achieved then cells within the TCL may redifferentiate into organs exhibiting correct developmental patterns leading to phenotypically normal organ architecture (Teixeira da Silva and Nhut, 2003a). TCLs have been used as a model system to analyse biochemical and molecular markers of differentiation (Biondi et al., 2001).

Within the TCL system the morphogenic and developmental pathways of specific organs - derived from other specific or non-specific cells, tissues or organs - may be clearly directed and controlled. Moreover, it allows for the study of cytological, physiological, biochemical and molecular changes occurring in a particular morphogenic program. This strict regulation of the morphogenic pathways will allow for, inter alia, the controlled production of somatic embryos and their subsequent use as synthetic seed, or as mass propagation units. It would also enhance the production capacity of secondary metabolites and pharmaceuticals through transgenic organ cultures, such as those produced by Agrobacterium rhizogenes, or by other autotrophic bioreactor plant cultures. The efficiency of genetic transformation is clearly enhanced as a result of cell and/or tissue specificity of gene insertion, and the subsequent successful and controlled regeneration of transformed tissue. Moreover, the use of TCLs allows for the potential production of in vitro flowers (independent of or in conjunction with photoperiod, vernalization and/or other environmental cues), and can be used as an explant source, or potentially as a new, long-term ornamental propagule, eliminating the problem of postharvest deterioration.

\section{MODEL SYSTEMS: TOBACCO, LILY AND CHRYSANTHEMUM}

Three plants (Nicotiana tabacum, Lilium longiflorum, Dendranthema grandiflora) have been intensively studied in terms of morphogenesis, organ differentiation and development using TCLs, and consequently have been considered the model plants for TCL systems.

Tobacco (Nicotiana tabacum) is one of the most well studied plants, and since the inception of the term and concept of a TCL (Tran Thanh Van, 1973), it has become the model system on which all other TCL studies are based. Four morphogenic programs: direct flower formation, direct root formation, direct bud formation, and callus without organogenesis, were induced from tobacco (Nicotiana tabacum Wisc.38) ITCLs, which were excised from floral ramifications (Tran Thanh Van and Trinh, 1986). This was possible by varying the concentration of carbohydrates and PGRs, light conditions and humidity (Table 1). A shift from the floral state to the vegetative state was possible by the addition of cell wall oligosaccharides to the medium, suggesting that oligosaccharides released by PGR-treatment of TCLs (Tran Thanh Van et al., 1985) or by pH (Cousson et al., 1989) can act as signaling molecules. All organs and callus arose from the subepidermal layer. Other factors controlling morphogenesis in TCLs could be carried out by controlling light, sugar and oligosaccharide 
Table 1. Studies of morphogenesis in model plants (tobacco, lily, chrysanthemum) using TCLs.

\begin{tabular}{|c|c|c|c|c|c|c|c|c|c|}
\hline Species & Program & Explant source & PGRs* & Additives*1 & L/D & I/tTCL & Organs/TCL & DT & Reference \\
\hline Nicotiana tabacum & $\begin{array}{l}\text { Flower } \\
\text { Vegetative bud } \\
\text { Root } \\
\text { Callus }\end{array}$ & $\begin{array}{l}\text { Pedicel } \\
\text { Pedicel } \\
\text { Pedicel } \\
\text { Pedicel }\end{array}$ & $\begin{array}{l}1 \mathrm{IBA} ; 1 \mathrm{~K} \\
1 \mathrm{IBA} ; 10 \mathrm{~K} \\
10 \mathrm{IBA} ; 0.1 \mathrm{~K} \\
3 \mathrm{IBA} ; 0.1 \mathrm{~K}\end{array}$ & $\begin{array}{l}\text { Glucose } 30 \\
\text { Sucrose } 30 \\
\text { Sucrose } 10 \\
\text { Sucrose } 30\end{array}$ & $\begin{array}{l}\mathrm{L} \\
\mathrm{L} \\
\mathrm{L} / \mathrm{D} \\
\mathrm{L}\end{array}$ & $\begin{array}{l}\text { ITCL } \\
\text { ITCL } \\
\text { ITCL } \\
\text { ITCL }\end{array}$ & $\begin{array}{l}30-50 \\
500-800 \\
10-20 \\
-\end{array}$ & $\begin{array}{l}12-21 \\
10-12 \\
16-18 \\
8-10\end{array}$ & $\begin{array}{l}\text { Tran Thanh Van and Trinh, } 1986 \\
\text { Ibid. } \\
\text { Ibid. } \\
\text { Ibid. }\end{array}$ \\
\hline Lilium longiflorum & $\begin{array}{l}\text { Pseudo-bulblet } \\
\text { Bulblet/shoot } \\
\text { Bulblet } \\
\text { Pseudo-bulblet } \\
\text { Bulblet } \\
\text { Root } \\
\text { Shoot } \\
\text { PLB } \\
\text { SE } \\
\text { SE }\end{array}$ & $\begin{array}{l}\text { Young leaf } \\
\text { Pseudo-bulblet } \\
\text { Receptacle/ovary } \\
\text { Stem node } \\
\text { Young stem } \\
\text { Young stem } \\
\text { Young stem } \\
\text { Young stem } \\
\text { Young stem } \\
\text { Pseudo-bulblet }\end{array}$ & $\begin{array}{l}2 \mathrm{BA} ; 6 \text { NAA } \\
\text { 1-3 CPPU } \\
2 \mathrm{BA} ; 5 \mathrm{NAA} \\
\text { 1-2.3 BA } \\
5.4 \mathrm{NAA} \\
2.22,4-\mathrm{D} \\
1 \mathrm{IBA} \\
1.1 \mathrm{TDZ} \\
\text { 5.4 NAA } 0.4 \mathrm{TDZ} \\
\text { 1.1 NAA 2.2 TDZ }\end{array}$ & $\begin{array}{l}\text { Sucrose } 30 \\
\text { Sucrose } 20-90 \\
\text { Sucrose } 30 \\
\text { Sucrose } 20 \\
\text { Sucrose } 20 \text { AC } 1 \\
\text { Sucrose } 20 \text { AC } 1 \\
\text { Sucrose } 20 \text { AC } 1 \\
\text { Sucrose } 20 \text { AC } 1 \\
\text { Sucrose } 20 \text { AC } 1 \\
\text { Sucrose } 30\end{array}$ & $\begin{array}{l}\mathrm{L} \\
\mathrm{L} \\
\mathrm{L} \\
\mathrm{L} \\
\mathrm{L} \\
\mathrm{L} \\
\mathrm{L} \\
\mathrm{L} \\
\mathrm{L} \\
\mathrm{L}\end{array}$ & $\begin{array}{l}\text { tTCL } \\
\text { tTCL } \\
\text { tTCL } \\
\text { tTCL } \\
\text { tTCL } \\
\text { tTCL } \\
\text { tTCL } \\
\text { tTCL } \\
\text { tTCL } \\
\text { tTCL }\end{array}$ & $\begin{array}{l}8 \\
15 \\
41 \\
2\end{array}$ & $\begin{array}{l}28 \\
35 \\
42 \\
28 \\
\\
14\end{array}$ & $\begin{array}{l}\text { Nhut, } 1998 \\
\text { Nhut et al., 2002b } \\
\text { Nhut and Teixeira da Silva, 2001h } \\
\text { Nhut et al., 2001b } \\
\text { Nhut et al., 2001a; 2001b } \\
\text { Ibid. } \\
\text { Ibid. } \\
\text { Ibid. } \\
\text { Nhut et al., 2001d; 2002a } \\
\text { Nhut et al., 2001a }\end{array}$ \\
\hline Dendranthema grandiflora & $\begin{array}{l}\text { SE, shoot } \\
\text { Root }\end{array}$ & $\begin{array}{l}\text { Stem internode } \\
\text { Stem internode }\end{array}$ & $\begin{array}{l}\text { 1-3 2,4-D 1-3 TDZ } \\
\text { 1-3 NAA } 1 \text { IBA }\end{array}$ & $\begin{array}{l}\text { Sucrose } 20 \\
\text { Sucrose } 40\end{array}$ & $\begin{array}{l}\mathrm{L} / \mathrm{D} \\
\mathrm{L} / \mathrm{D}\end{array}$ & $\begin{array}{l}\text { tTCL } \\
\text { tTCL }\end{array}$ & $\begin{array}{l}1-3 \\
2-3\end{array}$ & $\begin{array}{l}15-21 \\
5-8\end{array}$ & $\begin{array}{l}\text { Teixeira da Silva and Fukai, } 2003 \\
\text { lbid. }\end{array}$ \\
\hline
\end{tabular}

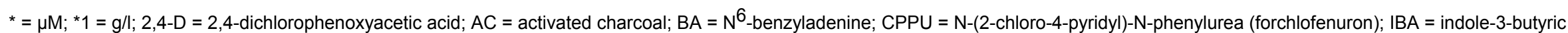

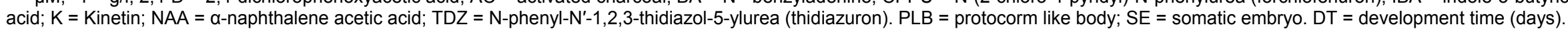


concentration, ionic composition of the culture medium and $\mathrm{pH}$ (Cousson and Tran Thanh Van, 1992; Tran Thanh Van et al., 1985). The flower program can only be induced on TCLs excised from floral branches and not from the base of the stem (Tran Thanh Van, 1973). There is a more comprehensive review on tobacco tissue culture and TCL applications (Nhut et al., 2003a).

Lilies (Lilium longiflorum) are fast becoming one of the most important bulbous crop species globally. The traditional asexual propagation of Lilium spp. by bulb scales as well as the lack of efficient micropropagation systems for species within the Lilium genus prompted extensive studies of TCL as a tool and solution for these shortcomings (reviewed in Nhut et al., 2001a). Since TCLs have been used extensively to study lily differentiation, and with the successful manipulation of all morphogenic programs (Table 1), it has been considered as a model system. In an attempt to test the effect of tTCL explant source (receptacle, stem node and internode, pseudo-bulblet, leaf) together with different factors such as sucrose concentration, explant position, activated charcoal (AC) and PGRs on the mass propagation of Lilium was studied (Nhut et al., 2001b). For all the studies on bulblet formation using TCL methods, a MS/2 medium supplemented with 1-2.7 $\mu \mathrm{M} \alpha-$ naphthalene acetic acid (NAA) or $10 \mu \mathrm{M}$ indole-3-butyric acid (IBA) and sucrose at concentrations from 20-30 g/l was used for the rooting of shoots, bulblets and pseudobulblets. Plantlets obtained in the light developed well on this medium and were subsequently transferred to the greenhouse, with a $90-100 \%$ survival rate. When young leaf explant tTCLs $(0.3 \mathrm{~mm})$ were excised and cultured on MS medium supplemented with $3 \%$ sucrose and $2 \mu \mathrm{M}$ BA combined with $6 \mu \mathrm{M}$ NAA (Nhut, 1998), pseudobulblets formed, mainly on the adaxial surface. Shoots regenerated from pseudo-bulblet tTCLs using forchlofenuron (CPPU), while a maximum of 15 bulblets can be obtained from one pseudo-bulblet tTCL. At low sucrose concentrations $(2-4 \%)$ shoots were obtained, but at high concentrations (6-9\%) bulblets formed (Bui et al., 1999a; Nhut, 2001c; Nhut et al., 2002b). When receptacle tTCLs were used, buds appeared within 3 weeks of culture, but not in the ovary or flower stalks (Nhut et al., 2001a). These buds continued to develop into bulblets. Stem node $(2-3 \mathrm{~mm}) \mathrm{tTCL}$ sections from plantlets derived from shoot tips of dormant bulbs formed pseudo-bulblets, which developed into the flowering stage without dormancy being observed (Nhut et al., 2001b). tTCL square epidermal layers from young stems could form an average of 4 bulblets was formed per tTCL after 4 weeks culture (Nhut et al., 2001a). Shoots did not form in activated charcoal (AC)-free medium, indicating that $A C$ has the same effect as a cytokinin-like hormone on the development of tTCL explants. In other studies (Nhut et al., 2001d; 2002a), similarly prepared transverse young stem sections of $L$. longiflorum were shown to form different organs (bulblets, roots, shoots, plantlets, PLBs, somatic embryos) when explants were exposed to different PGRs. Somatic embryogenesis has been achieved in tTCLs of in vitro L. longiflorum pseudo-bulblet explants (Nhut et al., 2001a).

TCLs have recently been used to study the effect of numerous media additives (carbon source, antibiotics, PGRs, inter alia) and conditions on regeneration and morphogenesis in chrysanthemum. A more comprehensive review on chrysanthemum also highlights these studies (Teixeira da Silva, 2003). The controlled production of roots, shoots or somatic embryos could be achieved when stem internode tTCLs were placed on various media (Table 1; Figure 1; Teixeira da Silva and Fukai, 2003).

\section{APPLIED TCL SYSTEMS}

Numerous plants are used as ornamentals for decoration, cut flowers, landscaping and gardening. Below are some ornamentals which, using conventional micropropagation systems have resulted in multiple morphogenic programs, but following the use of the TCL system, have resulted in individual morphogenic programs.

African violet (Saintpaulia ionantha). Direct bud organogenesis (vegetative bud, callus, roots, somatic embryo, polyembryonic-like structure) was achieved in this commercially important micropropagated ornamental perennial when the auxin/cytokinin (NAA:BA or TDZ) ratio in the TCL (derived from leaf petioles to the central nerve (leaf vein) and lamina) culture medium was strictly controlled. An average of $100-200$ shoots per tTCL explant were obtained from $0.3-0.5 \mathrm{~mm}$ petiole or $3 \times 3$ $\mathrm{mm}$ lamina sections, respectively, within 4 weeks culture. Over 70.000 plants were produced from a single leaf within 3-4 months (Ohki, 1994).

Amaranth (Amaranthus edulis). Amaranthus are popular for dry flower production, bedding and indoor plants. As a crop, they have a rich lysine content, about $18 \%$ higher than cereals. Shoots and embryo-like structures (ELSs) were obtained when 0.2-0.4 mm tTCLs excised from apical and subapical zones of Amaranthus seedlings formed directly on the epidermal cells of after one week on MS with $3 \mu \mathrm{M}$ TDZ (Bui et al., 1998a).

Begonia (Begonia rex). Over 2000 species of Begonia are already classified with more varieties increasing every year by traditional breeding methods. The major target of breeding is alteration of plant morphology, leaf and/or flower colour. Begonia is one of the most popular ornamental plants in the world and is used as garden plants, potted plants, hanging baskets, and greenhouse flowers. One to six epidermal cell layers and subjacent collenchyma cells excised from the main vein of leaves were cultured on a mineral solution containing $1 \%$ sucrose 


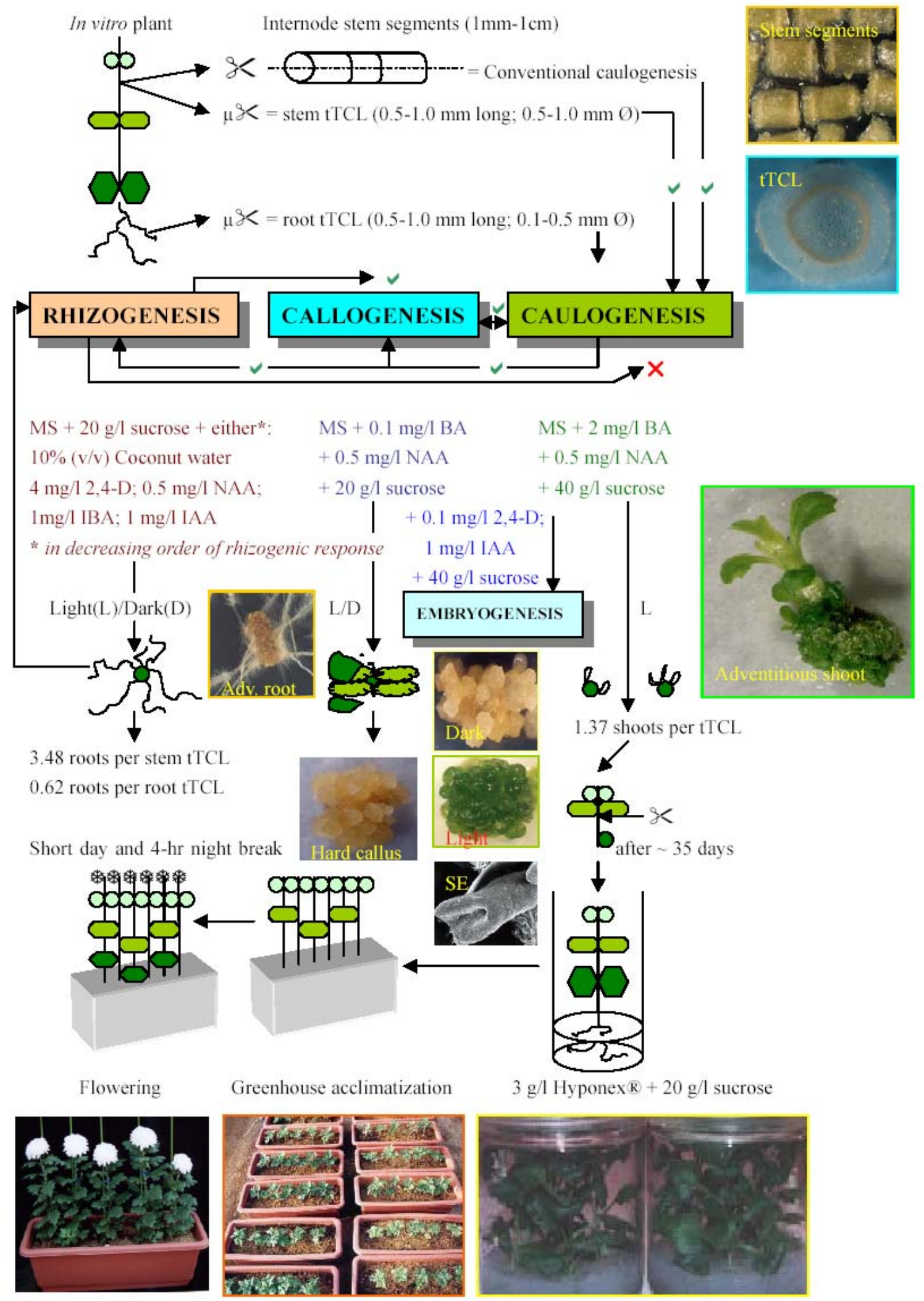

Figure 1. Flow diagram indicating the origin of tTCLs, and the induction of a rhizogenic (root), callogenic (callus), caulogenic (shoot) or somatic embryogenic programmes. Following the harvest of shoots (the most important organ for chrysanthemum regeneration and transformation studies), these may be rooted in vitro on Hyponex-supplemented agar medium, then acclimatized in the greenhouse to $100 \%$, then induced to flower under short day conditions. 
and $10 \mathrm{~g} / \mathrm{l}$ agar, to which $1 \mu \mathrm{M}$ BA was added for bud formation, or $0.5 \mu \mathrm{M}$ NAA for root formation, or $0.1 \mu \mathrm{M}$ NAA for unicellular hair formation. This new morphogenetic program, expressed after 6 days of culture, represents one of the simplest types of differentiation (Chlyah and Tran Thanh Van, 1975).

Gentian (Gentiana spp.). Gentians (Gentiana spp) are herbaceous perennial plants with high ornamental value use as cut and potted flowers, and in landscaping. Gentians, relatively recalcitrant species for shoot regeneration, could be mass propagated when 0.3-0.5 $\mathrm{mm}$ tTCLs, excised from floral stalk receptacles, were cultured on $50 \mu \mathrm{M}$ TDZ and $1 \mu \mathrm{M}$ NAA (Hosokawa et al., 1996). In TDZ-less medium the percentage of buds per tTCL is low. Many buds developed after 2-4 weeks directly on the surface of receptacle tTCLs.

\section{Geranium hybrid (Pelargonium $x$ hortorum).} Geraniums are popular garden plants used specifically for their decorative or scented foliage while the bushy flowering geraniums have showy flowers suitable for gardens, windowboxes or hanging baskets. Gill et al. (1992) showed that in tTCL hypocotyls explants $(1 \times 10$ $\mathrm{mm}$ ) of 1-week-old geranium hybrid seedlings, somatic embryos could form in response to TDZ or a combination of IAA and BA, but the number of embryos was much less in the latter than with 1-1.5 $\mu \mathrm{M}$ TDZ. The development of somatic embryos was rapid and the number of embryos was about 8-fold higher than in the culture of whole hypocotyl explants. In tTCLs globular or early heart-shaped somatic embryos were formed within one week of culture, whereas in the whole hypocotyl explants they were visible only after 2 weeks. Hypocotyls from a 1-week-old plant can be the source of at least 5 and as many as 10 tTCLs, each of which can develop into about 40-60 embryos, giving a total of 400-600 embryos per hypocotyl, as compared to approximately 50 embryos which can form directly from a whole hypocotyl of similar size and age. tTCLs of 1-week-old seedlings produce a higher number of somatic embryos than those obtained from older seedlings, and regenerated somatic embryos develop into complete plantlets within 6 to 8 weeks of culture initiation.

Gladiola (Gladiolus spp.). The genus Gladiolus from the family Iridaceae comprises about 180 species, and numerous cultivars and hybrids that are of ornamental value as cut flowers. For the mass propagation of Gladiolus within a short time interval, Gladiolus in vitro cormel tTCLs were aseptically cultured from corms on medium containing $10 \mu \mathrm{M}$ BA (Stefaniak, 1994). After one month cormels developed on the surface of originally cultured cormels, near the axilary buds. In vitro cormel tTCL explants (0.3-0.5 mm) were excised and cultured on medium containing different concentrations of TDZ (1-10 $\mu \mathrm{M})$. After two weeks, direct bud primordia without an intermediate callus phase were observed on the surface of tTCL explants at an optimal concentration of 1-3 $\mu \mathrm{M}$ TDZ. More than 50 buds per tTCL could be recovered after 3 weeks culture.

Heliconia (Heliconia spp.). Several species in this genus are floral crops because of their showy and brightly hued terminal inflorescences. Goh et al (1995) used TCLs to efficiently direct organogenesis. Stem tTCLs from the shoot apex $(0.8-1 \mathrm{~mm})$ of $H$. psittacorum $L$. 'Choconiana' were cultured in vitro on MS with $80 \mu \mathrm{M}$ 2,4-D, forming callus and PLBs, which developed and grew into plantlets after two 6-week subcultures on basal MS. The TCL system was used for both mass propagation and germplasm conservation of Heliconia species.

Iris (Iris pallida). Many Irises are ornamental plants such as I. hollandica or I. pallida. Furthemore, I. pallida is also a source of $y$-irone. Thin sections $(0.3-0.5 \mathrm{~mm})$ made across a mature shoot (comprising 5-6 leaves) and from the base toward the apex were cultured. Somatic embryogenesis occurred on young leaf base tTCLs (Tran Thanh Van and Bui, 1999). Protocols have been extensively utilized using thin sections for the plant regeneration of Irises (Gozu et al., 1993).

Orchids. Orchids are one of the most attractive groups of cut flower and ornamental potted plants. Many commercial firms use in vitro systems for the rapid mass plant propagation of various orchids, although only few reports exist in the literature. To mass produce a monopodial orchid hybrid Aranda 'Deborah' Laskshmanan et al. (1995) used 0.6-0.7 mm thick tTCLs from a single shoot tip (6-7 mm). After 45 days of culture, neoformation of PBLs occurred on the same culture medium, 13.6 PBLs per TCL and 2.7 PBLs per shoot tip. The addition of $2.75 \mu \mathrm{M}$ NAA to the same medium further increased PLB production (19.2 PBLs per TCL). The advantage of the tTCL system is to produce a high frequency of shoot regeneration and to reduce the time interval required, with potentially more than 80,000 plantlets produced from a single tTCL in a year as compared to the 11,000 plantlets produced by the conventional shoot tip method. Among monocot orchid species such as Phaleanopsis, young leaf lamina TCL explant $\left(4 \mathrm{~mm}^{2}\right)$ or floral stalks can be induced to form protocorms directly along the wounded edges of the lamina and on the surface of the TCL (Tran Thanh Van, 1974). The use of CPPU $(10 \mu \mathrm{M})$ with a low sucrose concentration $(1 \%)$ caused the highest percentage of explant $(95 \%)$ shoot growth and rooting in Rhynchostylis gigantean (Bui et al., 1999b). 
Petunia (Petunia hybrida). Petunia is one of the world's favourite gardening and potting annuals responsible for rapid and large economic turnovers. Mulin and Tran Thanh Van (1989) showed that in vitro shoots and flowers are formed from thin epidermal cells excised from the first five internodes of basal flowering branches in Petunia hybrida. Explants $\left(1 \times 10 \mathrm{~mm}^{2}\right)$ consisted of $3-6$ layers of subepidermal and epidermal cells and when placed on basal MS with $1 \mu \mathrm{M}$ each of IAA or Kinetin, vegetative buds formed after 2 weeks and developed into vegetative shoots in all genotypes tested. In contrast, in vitro floral buds were obtained when all stages of flowering (floral buds to faded flowers) were present on basal flowering branches of the mother plant. Other morphogenic programs were observed when medium PGRs were modified, such as the substitution of $1 \mu \mathrm{M}$ Kinetin by $10 \mu \mathrm{M}$ BAP, resulting in vegetative bud formation, or when $1 \mu \mathrm{M}$ IAA was replaced by $10 \mu \mathrm{M}$ IBA or when Kinetin was used at $0.1 \mu \mathrm{M}$ instead of $1 \mu \mathrm{M}$, root formation was obtained. A combination of $100 \mu \mathrm{M}$ 2,4-D and $0.1 \mu \mathrm{M}$ Kinetin induced callus.

Rose (Rosa spp.). Rose is one of the four major cut flower species commercially explored worldwide. ITCLs were excised longitudinally from dormant bud floral stalks and cultured on a full-or half MS, supplemented with $0.05-5 \mathrm{mg} / \mathrm{l} 2,4-\mathrm{D}$ or NAA usually in combination with a BAP, Zeatin or Kinetin. Preincubation at a high $(100 \mu \mathrm{M})$ 2,4-D concentration increased the frequency of both organogenic and embryogenic callus from Rosa hybrida 'Baccara' leaf explants (Hsia and Korban, 1996). Sucrose at $2-3 \%$ was used as the sole carbon source in most cases. However, replacement of sucrose by galactose or fructose increased somatic embryogenesis from leaf explants of some $R$. hybrida cultivars. Breaking of bud dormancy in roses is important for rapid multiplication of roses using grafting. ITCLs cultured on medium with 10 $\mu \mathrm{M}$ BAP and $3 \mu \mathrm{M} \mathrm{GA}{ }_{3}$ resulted in more than 7 buds per ITCL after 4 weeks culture.

Sunflower (Helianthus annuus). Sunflower is a popular ornamental and cut flower, with many cultivars used in gardening and landscaping. Different hypocotyl Helianthus annuus tTCLs were compared for their embryogenic and callogenic capacities: a) $2 \mathrm{~cm}$ long segments of hypocotyls, b) hypocotyls without epidermis, c) monolayer of epidermis, d) subepidermal layer, e) epidermis plus parenchyma layers, cultured on medium with $1 \mathrm{mg} / \mathrm{l} \mathrm{NAA}, 1 \mathrm{mg} / \mathrm{l} \mathrm{BA}$ and $20 \mathrm{ml} / \mathrm{l}$ coconut water (Pélissier, 1990). The epidermal monolayer, the subsepidermal layers and the hypocotyls without epidermis were not embryogenic. Only the tTCLs comprising the epidermis plus parenchyma layer and the hypocotyls segments were embryonic. The primary somatic embryos that differentiated on Helianthus TCLs gave rise to secondary embryos, which developed into normal fertile plants.

\section{TCL AS A TOOL FOR GENETIC ENGINEERING AND CROP IMPROVEMENT}

Plant transformation is a core technology in the genetic engineering of plants, and is normally composed of three processes: 1) the introduction of genes into plant cells; 2) selection of transgenic cells and 3 ) regeneration of transgenic plants. However the limiting factor has often been the third step. Without successful regeneration, in a controlled and defined manner, leading to the formation of organs or plants that are genetically and physiologically normal, there will be no success of stable transgene expression. Often initial explants utilized in the regeneration procedure are too large, and the capacity of both transformed and untransformed cells (following the gene introduction method) to regenerate is the same, especially if the selection level is low, or if the regenerating shoots arise from the surface of cells not in contact with the selection medium, or from within the explant, where the selective agent has not had time to diffuse through the explant, and exert its selective pressure. This results in chimerism and the formation of escapes. The utilization of TCLs eliminates the presence of untransformed cells and subsequent chimerism, and exposes all cells on the thin layer to the selective medium. Only cells harbouring the selector gene within their genome proliferate on the selective medium. Success of transformation varies widely between ornamental species, and has been achieved primarily by Agrobacteriummediated gene transfer, and to a lesser extent by direct gene transfer (particle bombardment, electroporation, electrophoresis, silicon fibres, magnetite particles, or protoplast manipulation). The reports on the use of a TCL system as an initial explant for gene transfer are few, but those that exist demonstrate the effectiveness of introducing a gene into an explant with defined cellular structure and with a controlled regeneration program, allowing for the formation of non-chimeric transgenic plants.

Transgenic tobacco plants derived from tTCLs transformed with the ro/B gene have more pronounced rhizogenesis and flowering, and appear to be involved in the promotion of meristem formation (Altamura et al., 1994). The effectiveness of transformation also depends on cell competence for both regeneration and transformation (Creemers-Molenaar et al., 1994). Tobacco 'Samsun' ITCLs excised from floral pedicels were cultured to induce vegetative buds to study the cell competence for regeneration and transformation by biolistics (Tran Thanh Van, 1980). Ten days pre-culture was the optimal period for obtaining genetic transformants.

Gladiolus tTCLs at pre-mature bud stage (15 days on medium with $3 \mu \mathrm{M}$ TDZ) were transformed using biolistic transformation. Thus the preculture period necessary for induced cell competent for plant regeneration from TCL explants is an important factor for transgenic plant 
formation. Moreover TCL explants have an increased surface when infected or exposed to Agrobacterium or biolistic transformation.

TCLs have been used as an explant source for the study of transformation, with transgenic plants obtained for Brassica napus (Charest et al., 1988), Nicotiana plumbaginifolia (Trinh et al., 1987), and Digitaria sanguinalis (Bui et al., 1998b). In Brassica napus ssp. olifera 'Westar' tTCLs a high frequency of transformation (40-50\%) was obtained when tTCLs were Agroinfected for $30 \mathrm{~s}$ and co-cultivated for 2 days before the addition of an antibiotic (Charest et al., 1988). In Nicotiana plumbaginifolia tTCLs, transformants were obtained on a $100 \mathrm{mg} / \mathrm{l}$ kanamycin selective medium after co-cultivation with $A$. tumefaciens for 2 days (Trinh et al., 1987). Transgenic plants with the bar gene were confirmed by Southern analysis, revealing 3 basta-resistant lines when Digitaria sanguinalis tTCLs were biolistically transformed (Bui et al., 1998b).

Successful transformation of Dendranthema grandiflora was obtained when stem tTCLs or leaf ITCLs were used as initial explant sources, using both Agrobacterium-mediated transformation, and biolistics (Teixeira da Silva and Fukai, 2002a; 2002b).

\section{CONCLUDING REMARKS}

All patterns of morphogenesis displayed by a plant (callus, root, shoot, flower, somatic embryo) can be induced either separately or in combination, each with a welldefined reversible/irreversible phase. Plant tissue culture and molecular biotechnology are at an important crossroad where one or the other cannot solely be utilized to achieve the successful analysis of in vitro or in planta physiological and genetic systems. Both have powerful techniques that permit the understanding of mechanisms that control processes such as transgene expression, in vitro flowering and morphogenesis. TCL systems have been used extensively as a tool that allows for the understanding of these processes, and opens the way for new research that may further elucidate certain physiological and genetic pathways and processes, which, in plant tissue culture and molecular biotechnology, still remain a paradigm. The TCL system is a simplified system that requires only a small amount of plant material and medium volume (circ. $15 \mu \mathrm{l}$ per TCL), and provides a good system for the study of fundamental and applied aspects of regeneration and transformation. The TCL system has been effectively utilized to study organogenesis and embryogenesis in ornamental and floricultural species, and promises to be extended to the micropropagation of others.

\section{REFERENCES}

Altamura MM, Capitani F, Gazza L, Capone I, Costatino P (1994). The plant oncogene ro/B stimulates the formation of flower and root meristemoids in tobacco thin cell layers. New Phytol. 126:283-293.

Biondi S, Scaramagli S, Capitani F, Altamura MM, Torrigiani P (2001). Methyl jasmonate upregulates biosynthetic gene expression, oxidation and conjugation of polyamines and inhibits shoot formation in tobacco thin cell layers. J. Exp. Bot. 52:231-242.

Bui VL, Nghieng Thao DM, Jeanneau M, Sadik S, Tu S, Vidal J, Tran Thanh Van K (1998a). Rapid plant regneration of a $\mathrm{C}_{4}$ dicot species: Amaranthus edulis. Plant Sci. 132;45-54.

Bui VL, Jeanneau M, Nghieng Thao DM, Vidal J, Tran Thanh Van K (1998b). Rapid regeneration of whole plants in large crabgrass (Digitaria sanguinalis L.) using thin cell layer culture. Plant Cell Rep. 18:166-172.

Bui VL, Nhut DT, Tran Thanh Van K (1999a). Plant production via shoot regeneration from thin cell layer pseudo-bulblet explants of Lilium longiflorum in vitro. C. R. Acad. Sci, Paris 322:303-310.

Bui VL, Hang Phuong NT, Anh Hong LT, Tran Thanh Van K (1999b). High frequency shoot regeneration from Rhynchostylis gigantea (Orchidaceae) using thin cell layer. Plant Growth Regul. 28:179-185.

Charest PJ, Holbrook LA, Gabard J, lyer VN, Miki BI (1988). Agrobacterium-mediated transformation of thin cell layer explants from Brassica napus L. Theor. Appl. Genet. 75:438-445.

Chlyah A, Tran Thanh Van M (1975). Differential reactivity in epidermal cells of Begonia rex excised and growth in vitro. Physiol. Plant. 35:16-20.

Cousson A, Toubart P, Tran Thanh Van K (1989). Control of morphogenetic pathways in thin cell layers of tobacco by $\mathrm{pH}$. Can. J. Bot. 67:650-654.

Cousson A, Tran Thanh Van K (1992). Influence of ionic composition of the culture medium on de novo flower formation in tobacco thin cell layers. Can. J. Bot. 71:506-511.

Creemers-Molenaar J, Harkkert JC, Van Staveren MJ, Gilissen LJW (1994). Histology of the morphogenic response in thin cell layer explants from vegetative tobacco plants. Ann Bot. 73:547-555.

Gill R, Gerrath J, Saxena PK (1992). High-frequency direct embryogenesis in thin layer cultures of hybrid seed geranium (Pelargonium). Can. J. Bot. 71:408-413.

Goh CJ, Nathan MJ, Kumar PP (1995). Direct organogenesis and induction of morphogenic callus through thin section culture of Heliconia psittacorum. Sci Hort. 62:113-120.

Gozu Y, Yokoyama M, Nakamura M, Namba R, Yomogida K, Yanagi M, Nakamura S (1993). In vitro propagation of Iris pallida. Plant Cell Rep. 13:12-16.

Hosokawa K, Nakano M, Oikawa Y, Yamamura S (1996). Adventitious shoot regeneration from leaf, stem and root explants of commercial cultivars Gentiana. Plant Cell Rep. 15:578-581.

Hsia CN, Korban SS (1996). Factors affecting in vitro establishment and shoot proliferation of Rosa hybrida L. and Rosa chinensis minima. In Vitro Cell. Dev. Biol. - Plant 32:217-222.

Lakshmanan P, Loh CS, Goh CJ (1995). An in vitro method for rapid regeneration of a monopodial orchid hybrid Aranda Deborah using thin section culture. Plant Cell Rep. 14:510-514.

Mulin M, Tran Thanh Van K (1989). Obtention of in vitro flowers from thin epidermal cell layers of Petunia hybrida (Hort.). Plant Sci. 62:113-121.

Nhut DT (1998). Micropropagation of lily (Lilium longiflorum) via in vitro stem node and pseudo-bulblet culture. Plant Cell Rep. 117:913-916.

Nhut DT, Bui VL, Teixeira da Silva JA, Aswath CR (2001a). Thin cell layer culture system in Lilium: regeneration and transformation perspectives. In Vitro Cell. Dev. Biol. 37:516-523.

Nhut DT, Bui VL, Fukai S, Tanaka M, Tran Thanh Van K (2001b). Effects of activated charcoal, explant size, explant position and sucrose concentration on plant and shoot regeneration of Lilium longiflorum via young stem culture. Plant Growth Regl. 33:59-65.

Nhut DT, Bui VL, Tanaka M, Tran Thanh Van K (2001c). Shoot induction and plant regeneration from receptacle tissue of Lilium longiflorum. Sci. Hort. 87:131-138.

Nhut DT, Bui VL, Tran Thanh Van K (2001d). Manipulation of the morphogenetic pathways of Lilium longiflorum transverse thin cell layer explants by auxin and cytokinin. In Vitro Cell. Dev. Biol. - Plant 37:44-49.

Nhut DT, Huong NTD, Bui VL, Teixeira da Silva JA, Fukai S, Tanaka M (2002a). The changes in shoot regeneration potential of protocorm- 
like bodies derived from Lilium longiflorum young stem explants exposed to medium volume, $\mathrm{pH}$, light intensity and sucrose concentration pretreatment. J. Hort. Sci. Biotechnol. 77:79-82.

Nhut DT, Bui VL, Minh NT, Teixeira da Silva JA, Fukai S, Tanaka M, Tran Thanh Van K (2002b). Somatic embryogenesis through pseudobulblet transverse thin cell layers of Lilium longiflorum. Plant growth Reg. 37:193-198.

Nhut DT, Aswath CR, Teixeira da Silva JA, Bui VL, Thorpe T, Tran Thanh Van K (2003a). Tobacco thin cell layer morphogenesis. In: Thin cell layer culture system: regeneration and transformation applications. Nhut DT, Van Le B, Tran Thanh Van K, Thorpe T (eds.). Kluwer Academic Publishers, Dordrecht, The Netherlands, pp. 65134.

Nhut DT, Teixeira da Silva JA, Bui VL, Tran Thanh Van K (2003b). Thin cell layer studies of vegetable, leguminous and medicinal plants. In: Thin cell layer culture system: regeneration and transformation applications. Nhut DT, Van Le B, Tran Thanh Van K, Thorpe T (eds.). Kluwer Academic Publishers, Dordrecht, The Netherlands, pp. 387425.

Nhut DT, Teixeira da Silva JA, Bui VL, Tran Thanh Van K (2003c). Organogenesis of cereals and grasses by using thin cell layer technique. In: Thin cell layer culture system: regeneration and transformation applications. Nhut DT, Van Le B, Tran Thanh Van K, Thorpe $\mathrm{T}$ (eds.). Kluwer Academic Publishers, Dordrecht, The Netherlands, pp. 427-449.

Nhut DT, Teixeira da Silva JA, Bui VL, Thorpe T, Tran Thanh Van K (2003d). Thin cell layer technology in fruit crop regeneration. In: Thin cell layer culture system: regeneration and transformation applications. Nhut DT, Van Le B, Tran Thanh Van K, Thorpe T (eds.). Kluwer Academic Publishers, Dordrecht, The Netherlands, pp. 451472.

Nhut DT, Teixeira da Silva JA, Bui VL, Thorpe T, Tran Thanh Van K (2003e). Woody plant micropropagation and morphogenesis by thin cell layers. In: Thin cell layer culture system: regeneration and transformation applications. Nhut DT, Van Le B, Tran Thanh Van K, Thorpe T (eds.). Kluwer Academic Publishers, Dordrecht, The Netherlands, pp. 473-493.

Nhut DT, Teixeira da Silva JA, Bui VL, Tran Thanh Van K (2003f). Thin cell layer (TCL) morphogenesis as a powerful tool in woody plant and fruit crop micropropagation and biotechnology, floral genetics and genetic transformation. In: Micropropagation of woody trees and fruits. Jain SM, Ishii K (eds.). Kluwer Academic Publishers, Dordrecht, The Netherlands, pp. 783-814.

Ohki S (1994). Scanning electron microscopy of shoot differentiation in vitro from leaf explants of the African violet. Plant Cell Tiss. Org. Cult. 36:157-162.

Pélissier B, Bouchefra O, Pépin R, Freyssinet G (1990). Production of isolated somatic embryos from sunflower thin cell layers. Plant Cell Rep. 9:47-50.

Stefaniak B (1994). Somatic embryogenesis and plant regeneration of Gladiolus (Gladiolus hort). Plant Cell Rep. 13:386-389.

Teixeira da Silva JA (2003). Tissue culture and cryopreservation of chrysanthemum: a review. Biotechnol. Adv. 21:715-766.

Teixeira da Silva JA, Fukai S (2002a). Increasing transient and subsequent stable transgene expression in chrysanthemum (Dendranthema x grandiflora (Ramat.) Kitamura) following optimization of particle bombardment and Agroinfection parameters. Plant Biotechnol. 19:229-240.

Teixeira da Silva JA, Fukai S (2002b). Change in transgene expression following transformation of chrysanthemum by four gene introduction methods. Propagation Ornamental Plants 2:28-37.

Teixeira da Silva JA, Fukai S (2003). Chrysanthemum organogenesis through thin cell layer technology and plant growth regulator control. Asian J. Plant Sci. 2:505-514.

Teixeira da Silva JA, Nhut DT (2003). Cells: functional units of TCLs. In: Thin cell layer culture system: regeneration and transformation applications. Nhut DT, Van Le B, Tran Thanh Van K, Thorpe T (eds.). Kluwer Academic Publishers, Dordrecht, The Netherlands, pp. 65134.

Tran Thanh Van M (1973). In vitro control of de novo flower, bud, root and callus differentiation from excised epidermal tissues. Nature 246:44-45.
Tran Thanh Van M (1974). Methods of acceleration of growth and flowering in a few species of orchids. Amer. Orchid Soc. Bull. 43:699707.

Tran Thanh Van K (1980). Control of morphogenesis by inherent and exogenously applied factors in thin cell layers. Intl. Rev. Cytol. 32:291-311.

Tran Thanh Van K, Toubart P, Cousson A, Darvill AG, Gollin DJ, Chelf $P$, Albersheim $P$ (1985). Manipulation of the morphogenetic pathways of tobacco explants by oligosaccharins. Nature 314:615-617.

Tran Thanh Van K, Trinh TH (1986). Fundamental and applied aspects of differentiation in vitro and in vivo. In: Handbook of plant cell culture, techniques and application. Evans DA, Sharp WR, Ammirato PV (eds.). Vol 4, McMillan Publishing Company, New York, pp. 316-335.

Tran Thanh Van K, Bui VL (2000). Curent status of thin cell layer method for the induction of organogenesis or somatic embryogenesis. In: Somatic embryogenesis in woody plants, Vol 6. Mohan SJ, Gupta PK, Newton RJ (eds.). Kluwer Academic, Publishers, Dordrecht, pp. 51-92.

Trinh TH, Mante S, Pua EC, Chua NH (1987). Rapid production of transgenic flowering shoots and F1 progeny from Nicotiana plumbaginifolia epidermal peels. Biotechnology 5:1081-1084. 